\title{
PELAKSANAAN STANDAR PELAYANAN KEFARMASIAN DI APOTEK KOTA PALU
}

\section{Khusnul Diana, Muhamad Rinaldhi Tandah, Muhammad Basuki}

\author{
Jurusan Farmasi, Fakultas Matematika dan Ilmu Pengetahuan Alam, Universitas Tadulako, Palu
}

Email: khusnul diana@yahoo.com

\begin{abstract}
The standard of pharmaceutical service is a benchmark or guideline for parmacist in carrying out pharmaceutical service in pharmacy facilities, one of them is pharmacy, in order to realize optimal health in the community. This study aims to describe the implementation of standard pharmaceutical services at the pharmacy in Palu city. This study was an observational study with descriptive qualitative data, data collection was cross sectional with the total number of samples are 56 respondents pharmacists / pharmacy in Palu city. Data was collected using questionnaire sheets distributed to respondents. From the results of the study, the standard clinical pharmacy services performed by pharmacists in the form of prescription study activities (61.6\%), dispensing (36.9\%), counseling (52.5\%). The standard of drug management, medical devices and medical disposable carried out by pharmacist (54.3\%). Clinical service standards that were not implemented at the pharmacy in the form of drug information services (62.1\%), monitoring drug therapy (78.3\%) and monitoring drug side effects (89.9\%).
\end{abstract}

Key Words : Pharmacies, pharmacists, pharmaceutical service standards.

\section{PENDAHULUAN}

Praktik kefarmasian yang termuat dalam Undang-Undang Nomor 36 Tahun 2009 tentang Kesehatan menyebutkan bahwa praktik kefarmasian meliputi pembuatan termasuk pengendalian mutu sediaan farmasi, pengamanan, pengadaan, penyimpanan dan pendistribusian obat, pelayanan obat atas resep dokter, pelayanan informasi obat serta pengembangan obat, bahan obat dan obat tradisional harus dilakukan oleh tenaga kesehatan yang mempunyai kemampuan/ keahlian dan kewenangan yang sesuai dengan ketentuan peraturan perundangundangan yang ada. Kegiatan praktik kefarmasain tersebut dilakukan di sarana kefarmasian salah satunya adalah apotek. Apotek merupakan salah satu sarana pelayanan kefarmasian kepada masyarakat, dalam melaksanakan pekerjaan kefarmasian yang dilakukan oleh apoteker maupun asisten apoteker yang benar dan bertanggung jawab. Dalam meningkatkan mutu pelayanan kefarmasian di apotek yang berorientasi kepada keselamatan pasien, diperlukan suatu standar yang digunakan sebagai acuan dalam melaksanakan pelayanan kefarmasian di apotek. ${ }^{1}$

Pelayanan kefarmasian dewasa ini telah bergeser orientasi, dari drug oriented menjadi patien oriented dan mengacu kepada pelaksanaan pharmaceutical care. Apoteker dituntut untuk selalu meningkatkan keterampilan dan pengetahuan serta perubahan perilaku agar dalam berinteraksi dengan pasien dapat dilakukan dengan baik. Bentuk-bentuk interaksi yang dilakukan baik oleh apoteker ataupun tenaga kefarmasian yang lain seperti pemberian informasi obat dan monitoring penggunaan obat dan melakukan konseling yang dibutuhkan oleh pasien dan masyarakat luas. Tenaga 
kesehatan kususnya apoteker perlu memiliki kesadaran dan memiliki pemahaman yang baik terhadap kemungkinan terjadinya medication error dalam proses pelayanan, sehingga dengan pelaksanaan pelayanan kefarmasian yang bertanggung jawab, dapat menurunkan kejadian kesalahan medication error, penyalahgunaan obat dan meningkatkan kepuasan masyarakat terhadap pelayanan kefarmasian yang telah dijalankan.

Standar pelayanan kefarmasian merupakan tolak ukur yang dipergunakan sebagai pedoman bagi tenaga kefarmasian dalam menyelenggarakan pelayanan kefarmasian. Standar pelayanan kefarmasian yang dilakukan di apotek termuat dalam Peraturan Menteri Kesehatan Republik Indonesia Nomor 73 Tahun 2016. Apoteker yang melakukan praktik kefarmasian di apotek selayaknya berpedoman kepada permenkes tersebut. Didalam standar pelayanan kefarmasian di apotek tersebut termuat kegiatan-kegiatan yang dilaksanakan dalam melayani pasien. Berdasarkan Satib (2016), disebutkan bahwa dalam peraturan tersebut menetapkan keharusan adanya pelayanan farmasi klinik di apotek. Pelayanan farmasi klinik di apotek merupakan bagian dari pelayanan kefarmasian yang langsung dan bertanggung jawab kepada pasien terkait dengan sediaan farmasi, alat kesehatan, dan bahan medis habis pakai dengan maksud mencapai hasil yang pasti untuk meningkatkan kualitas hidup (outcome) pasien. ${ }^{2}$

Dari latar belakang tersebut penting untuk diketahui gambaran pelaksanaan standar pelayanan kefarmasian di apotek kota Palu, sehingga dapat dijadikan bahan evaluasi dalam meningkatkan kinerja tenaga kefarmasian di apotek dalam melakukkan perkerjaan kefarmasian.

\section{METODE PENELITIAN}

Jenis penelitian ini adalah penelitian observasional (non eksperimental) dan bersifat deskriptif kualitatif dengan pendekatan waktu cross sectional yaitu penelitian yang pengukurannya dilakukan pada suatu saat tertentu saja atau sekaligus pada suatu saat (point time approach). Populasi adalah apotek, apoteker atau apoteker pendamping yang berpraktik di apotek wilayah Kota Palu. Data apotek didapat dari Dinas Kesehatan Kota Palu Tahun 2017, jumlah apotek yang terdaftar di wilayah Kota Palu berjumlah 182 apotek. Sampel yang digunakan adalah apoteker dan apotek yang memenuhi kriteria inklusi yaitu apoteker/apoteker pendamping yang berpraktek di apotek wilayah kota Palu dan apotek yang terdaftar dalam data Dinas Kesehatan Kota Palu Tahun 2017. Kriteria eksklusi yaitu responden/apoteker/apoteker pendamping yang tidak bersedia mengisi kuesioner, kuesioner tidak dikembalikan dan jawaban kuesioner tidak lengkap dan apotek yang tidak beroperasi lagi. Penelitian ini dilakukan di Apotek Wilayah Kota Palu pada bulan September - November 2017. Data dikumpulkan menggunakan lembar kuesioner yang berisi tentang karakteristik apoteker dan apotek serta pertanyaan seputar standar pelayanan kefarmasian di apotek berdasarkan Permenkes RI No. 73 Tahun $2016{ }^{3}$ dengan pilihan jawaban berupa checklist di salah satu jawaban atau lebih.

\section{HASIL DAN PEMBAHASAN}

\section{Karakteristik Sampel}

Berdasarkan data Dinas Kesehatan Kota Palu Tahun $2017^{4}$, terdapat 182 apotek 
yang terdata di Dinas Kesehatan Kota Palu dan sebanyak 5 apotek sudah tidak beroperasi, tetapi pada saat observasi didapat sebanyak 20 apotek sudah tidak beroperasi lagi. Sehingga sampel dalam penelitian ini yang memenuhi kriteria inklusi berjumlah 56 responden dan sebanyak 106 responden di ekslusi. Karakteristik sampel seperti terlihat pada tabel 1.

Tabel 1. Karakteristik Sampel Apoteker di Apotek Kota Palu

\begin{tabular}{|c|c|c|}
\hline Data Apoteker & Jumlah $(n=56)$ & Persentase (\%) \\
\hline \multicolumn{3}{|l|}{ Jenis Kelamin } \\
\hline Laki-laki & 14 & 25 \\
\hline Perempuan & 42 & 75 \\
\hline \multicolumn{3}{|l|}{ Jabatan di Apotek } \\
\hline Apoteker Pengelola Apotek (APA) & 56 & 100 \\
\hline Apoteker Pendamping (Aping) & 0 & 0 \\
\hline \multicolumn{3}{|l|}{ Lama Pengalaman sebagai APA } \\
\hline$\leq 1$ tahun & 13 & 23,21 \\
\hline$>1-5$ Tahun & 27 & 48,21 \\
\hline$>5-10$ Tahun & 12 & 21,43 \\
\hline$>10$ Tahun & 4 & 7,14 \\
\hline \multicolumn{3}{|l|}{ Imbalan per bulan } \\
\hline SRp. 2.000 .000 & 12 & 21,43 \\
\hline > Rp. 2.000 .000 - Rp. 3.000 .000 & 30 & 53,57 \\
\hline > Rp. 3.000 .000 - Rp. 4.000 .000 & 6 & 10,71 \\
\hline > Rp. 4.000 .000 & 1 & 3,33 \\
\hline Yang lain & 7 & 12,50 \\
\hline \multicolumn{3}{|l|}{ Memiliki Apoteker Pendamping } \\
\hline Tidak punya & 51 & 91,07 \\
\hline Punya & 5 & 8,93 \\
\hline \multicolumn{3}{|l|}{ Frekuensi Kehadiran } \\
\hline Selama apotek buka & 15 & 26,79 \\
\hline Setiap hari, pada jam tertentu & 29 & 51,79 \\
\hline Yang lain & 12 & 21,43 \\
\hline
\end{tabular}

Tabel 2. Karakteristik Apotek di Kota Palu

\begin{tabular}{lcc}
\hline \multicolumn{1}{c}{ Data Apotek } & Jumlah $(\mathbf{n}=\mathbf{5 6})$ & Persentase (\%) \\
\hline Jumlah resep per hari & & \\
< 5 lembar & 28 & 50,00 \\
5 - 10 lembar & 13 & 23,21 \\
10 - 20 lembar & 8 & 14,29 \\
20 - 30 lembar & 3 & 5,36 \\
> 30 lembar & 4 & 7,14 \\
\hline Rata-rata omset per hari & & \\
S Rp. 1.000.000 & 16 & 28,57 \\
Rp.1.000.000 - Rp.2.000.000 & 15 & 26,79 \\
Rp.2.000.000 - Rp.3.000.000 & 9 & 16,07 \\
Rp.3.000.000 - Rp.5.000.000 & 14 & 25,00 \\
$>$ Rp.10.000.000 & 2 & 6,67 \\
\hline
\end{tabular}


Tabel 3. Pelayanan Farmasi Klinik di Apotek Kota Palu

\begin{tabular}{|c|c|c|c|c|c|}
\hline \multirow[b]{2}{*}{ No. } & \multirow[b]{2}{*}{ Unit Kegiatan } & \multicolumn{4}{|c|}{ Persentase (\%) } \\
\hline & & $\begin{array}{l}\text { Oleh } \\
\text { Apoteker }\end{array}$ & $\begin{array}{c}\text { Oleh } \\
\text { Asisten } \\
\text { Apoteker }\end{array}$ & $\begin{array}{c}\text { Oleh Apoteker } \\
\text { dan Asisten } \\
\text { Apoteker }\end{array}$ & $\begin{array}{l}\text { Tidak } \\
\text { Dilakukan }\end{array}$ \\
\hline & Pengkajian resep & & & & \\
\hline $\mathrm{A} 1$ & Pemeriksaan kelengkapan resep & 64,3 & 7,1 & 21,4 & 7,1 \\
\hline A2 & Pemeriksaan keabsahan resep & 67,9 & 3,6 & 16,1 & 12,5 \\
\hline A3 & $\begin{array}{l}\text { Pertimbangan klinik terkait ketepatan indikasi dan dosis } \\
\text { obat }\end{array}$ & 78,6 & 1,8 & 8,9 & 10,7 \\
\hline A4 & Pertimbangan klinik terkait aturan pakai & 78,6 & 1,8 & 10,7 & 8,9 \\
\hline A5 & Pertimbangan klinik terkait duplikasi & 64,3 & 3,6 & 8,9 & 23,2 \\
\hline A6 & $\begin{array}{l}\text { Pertimbangan klinik terkait reaksi obat yang tidak } \\
\text { diinginkan (alergi, efek samping obat dIII) }\end{array}$ & 69,6 & 1,8 & 5,4 & 23,2 \\
\hline A7 & Pertimbangan klinik terkait kontraindikasi & 64,3 & 1,8 & 8,9 & 25,0 \\
\hline A8 & Pertimbangan klinik terkait interaksi obat & 66,1 & 1,8 & 8,9 & 23,2 \\
\hline A9 & $\begin{array}{l}\text { Pemeriksaan obat yang tersedia di apotek terhadap } \\
\text { permintaan pada resep }\end{array}$ & 46,4 & 19,6 & 26,8 & 7,1 \\
\hline A10 & Memeriksa kualitas fisik obat & 39,3 & 19,6 & 33,9 & 7,1 \\
\hline A11 & Memeriksa tanggal kadaluarsa obat & 28,6 & 26,8 & 35,7 & 8,9 \\
\hline \multirow[t]{3}{*}{ A12 } & $\begin{array}{l}\text { Apabila ada hal-hal dalam resep yang meragukan atau } \\
\text { tidak sesuai, maka menghubungi dokter penulis resep }\end{array}$ & 71,4 & 1,8 & 17,9 & 8,9 \\
\hline & Rata-Rata & 61,6 & 7,6 & 17,0 & 13,8 \\
\hline & Dispensing & & & & \\
\hline B13 & Menyiapkan obat sesuai dengan permintaan resep & 37.5 & 33.9 & 25.0 & 3.6 \\
\hline B14 & $\begin{array}{l}\text { Menghitung kebutuhan jumlah obat sesuai dengan } \\
\text { resep }\end{array}$ & 48.2 & 23.2 & 23.2 & 5.4 \\
\hline B15 & $\begin{array}{l}\text { Mengambil obat yang dibutuhkan pada rak } \\
\text { penyimpanan sesuai resep }\end{array}$ & 25.0 & 50.0 & 21.4 & 3.6 \\
\hline B16 & Melakukan peracikan obat (bila diperlukan) & 21.4 & 48.2 & 23.2 & 7.1 \\
\hline B17 & Memberikan etiket pada kemasan & 32.1 & 39.3 & 23.2 & 5.4 \\
\hline B18 & Memasukkan obat ke dalam wadah yang tepat & 25.0 & 51.8 & 17.9 & 5.4 \\
\hline B19 & Memeriksa ulang obat yang akan diserahkan & 64.3 & 12.5 & 17.9 & 5.4 \\
\hline B20 & Membuat salinan resep (bila diperlukan) & 53.6 & 19.6 & 19.6 & 7.1 \\
\hline \multirow[t]{3}{*}{ B21 } & Menyimpan resep pada tempatnya & 25.0 & 46.4 & 19.6 & 8.9 \\
\hline & $\begin{array}{ll}\text { Rata-Rata } \\
\end{array}$ & 36.9 & 36.1 & 21.2 & 5.8 \\
\hline & Pelayanan informasi obat & & & & \\
\hline $\mathrm{C} 22$ & Menjawab pertanyaan baik lisan maupun tulisan & 64.3 & - & 32.1 & 3.6 \\
\hline $\mathrm{C} 23$ & Membuat dan menyebarkan bulletin/brosur/leaflet & 12.5 & 5.4 & 5.4 & 76.8 \\
\hline C24 & Melakukan penyuluhan kepada masyarakat & 17.9 & - & 5.4 & 76.8 \\
\hline $\mathrm{C} 25$ & Memberikan informasi dan edukasi kepada pasien & 67.9 & - & 21.4 & 10.7 \\
\hline C26 & $\begin{array}{l}\text { Memberikan pengetahuan dan keterampilan kepada } \\
\text { siswa/mahasiswa yang sedang praktik }\end{array}$ & 28.6 & 1.8 & 10.7 & 58.9 \\
\hline C27 & Melakukan penelitian penggunaan obat & 7.1 & - & 1.8 & 91.1 \\
\hline C28 & $\begin{array}{l}\text { Membuat atau menyampaikan makalah dalam forum } \\
\text { ilmiah }\end{array}$ & 8.9 & - & - & 91.1 \\
\hline \multirow[t]{3}{*}{ C29 } & Melakukan program jaminan mutu & 12.5 & - & - & 87.5 \\
\hline & Rata-rata & 27.5 & 0.9 & 9.6 & 62.1 \\
\hline & Konseling & & & & \\
\hline D30 & Melakukan konseling yang terdokumentasi & 21.4 & - & 5.4 & 73.2 \\
\hline D31 & $\begin{array}{l}\text { Menilai pemahaman konsumen melalui three prime } \\
\text { questions }\end{array}$ & 44.6 & - & 5.4 & 50.0 \\
\hline D32 & Menggali informasi lebih lanjut kepada pasien & 66.1 & 1.8 & 10.7 & 21.4 \\
\hline D33 & $\begin{array}{l}\text { Memberikan penjelasan kepada pasien untuk } \\
\text { menyelesaikan masalah penggunaan obat }\end{array}$ & 69.6 & 3.6 & 12.5 & 14.3 \\
\hline \multirow[t]{3}{*}{ D34 } & $\begin{array}{l}\text { Melakukan verifikasi akhir untuk memastikan } \\
\text { pemahaman pasien }\end{array}$ & 60.7 & 1.8 & 10.7 & 26.8 \\
\hline & Rata-rata & 52.5 & 1.4 & 8.9 & 37.1 \\
\hline & Pemantauan terapi obat (PTO) & & & & \\
\hline E35 & $\begin{array}{l}\text { Memilih pasien yang memenuhi kriteria untuk dilakukan } \\
\text { PTO }\end{array}$ & 21.4 & - & 1.8 & 76.8 \\
\hline E36 & Mengambil data riwayat pengobatan pasien & 12.5 & - & 3.6 & 83.9 \\
\hline
\end{tabular}




\begin{tabular}{|c|c|c|c|c|c|}
\hline E37 & Melakukan identifikasi masalah terkait obat & 19.6 & - & 3.6 & 76.8 \\
\hline E38 & Menentukan prioritas masalah sesuai kondisi pasien & 30.4 & - & 3.6 & 66.1 \\
\hline E39 & $\begin{array}{l}\text { Memberikan rekomendasi atau rencana pemantauan } \\
\text { tindak lanjut }\end{array}$ & 25.0 & - & - & 75.0 \\
\hline E40 & $\begin{array}{l}\text { Melakukan komunikasi dengan tenaga kesehatan } \\
\text { terkait }\end{array}$ & 25.0 & - & - & 75.0 \\
\hline \multirow[t]{3}{*}{ E41 } & Melakukan dokumentasi pelaksanaan PTO & 5.4 & - & - & 94.6 \\
\hline & Rata-rata & 19.9 & - & 1.8 & 78.3 \\
\hline & Monitoring Efek Samping Obat (MESO) & & & & \\
\hline F42 & Melaksanakan MESO yang terdokumentasi & 5.5 & - & - & 94.5 \\
\hline F43 & $\begin{array}{l}\text { Mengidentifikasi obat dan pasien yang berpotensi } \\
\text { mengalami efek samping }\end{array}$ & 21.8 & - & - & 78.2 \\
\hline \multirow[t]{2}{*}{ F44 } & $\begin{array}{l}\text { Melaporkan ke Pusat Monitoring Efek Samping Obat } \\
\text { Nasional }\end{array}$ & 3.6 & - & - & 96.4 \\
\hline & Rata-Rata & 10.1 & - & - & 89.9 \\
\hline
\end{tabular}

Tabel 4. Kegiatan Pengelolaan Sediaan Farmasi, Alat Kesehatan dan Bahan Medis Habis Pakai di Apotek Kota Palu

\begin{tabular}{|c|c|c|c|c|c|}
\hline \multirow[b]{2}{*}{ No. } & \multirow[b]{2}{*}{ Unit Kegiatan } & \multicolumn{4}{|c|}{ Persentase (\%) } \\
\hline & & $\begin{array}{l}\text { Oleh } \\
\text { Apoteker }\end{array}$ & $\begin{array}{c}\text { Oleh } \\
\text { Asisten } \\
\text { Apoteker }\end{array}$ & $\begin{array}{l}\text { Oleh Apoteker } \\
\text { dan asisten } \\
\text { apoteker }\end{array}$ & $\begin{array}{l}\text { Tidak } \\
\text { Dilakukan }\end{array}$ \\
\hline G45 & Merencanakan pengadaan sediaan farmasi & 73.2 & - & 16.1 & 10.7 \\
\hline G46 & Pengadaan sediaan farmasi dari jalur resmi & 78.6 & - & 12.5 & 8.9 \\
\hline G47 & $\begin{array}{l}\text { Penerimaan sediaan farmasi sesuai dengan surat } \\
\text { pesanan }\end{array}$ & 53.6 & 12.5 & 26.8 & 7.1 \\
\hline G48 & Pengeluaran obat sesuai FIFO & 41.1 & 17.9 & 32.1 & 8.9 \\
\hline G49 & Pengeluaran obat sesuai FEFO & 42.9 & 16.1 & 32.1 & 8.9 \\
\hline G50 & Penyimpanan narkotika sesuai ketentuan & 51.8 & 3.6 & 10.7 & 33.9 \\
\hline G51 & Penyimpanan psikotropika sesuai ketentuan & 51.8 & 3.6 & 10.7 & 33.9 \\
\hline G52 & $\begin{array}{l}\text { Pemusnahan obat kadaluarsa /rusak sesuai dengan } \\
\text { jenis dan bentuk sediaan }\end{array}$ & 51.8 & 1.8 & 7.1 & 39.3 \\
\hline G53 & Pemusnahan resep setiap 5 tahun & 48.2 & - & 7.1 & 44.6 \\
\hline G54 & $\begin{array}{l}\text { Pengendalian persediaan obat menggunakan kartu stok } \\
\text { baik secara manual atau elektronik }\end{array}$ & 37.5 & 17.9 & 19.6 & 25.0 \\
\hline G55 & $\begin{array}{l}\text { Melakukan pencatatan sediaan farmasi, alkes dan } \\
\text { bahan medis habis pakai baik pada surat pesanan, } \\
\text { faktur, kartu stok, penjualan dan pencatatan lain yang } \\
\text { dibutuhkan }\end{array}$ & 35.7 & 19.6 & 30.4 & 14.3 \\
\hline G56 & $\begin{array}{l}\text { Melakukan pelaporan internal maupun eksternal } \\
\text { sediaan farmasi, alkes dan bahan medis habis pakai }\end{array}$ & 58.9 & 7.1 & 5.4 & 28.6 \\
\hline G57 & $\begin{array}{l}\text { Pelaporan narkotika dan psikotropika sesuai ketentuan } \\
\text { peraturan perundang-undangan }\end{array}$ & 80.4 & 1.8 & 5.4 & 12.5 \\
\hline & $\begin{array}{c}\text { Rata-rata } \\
\end{array}$ & 54.3 & 7.8 & 16.6 & 21.3 \\
\hline
\end{tabular}

Tabel 5. Pelaksanaa Standar Pelayanan Kefarmasian di Apotek Kota Palu

\begin{tabular}{|c|c|c|c|c|c|}
\hline \multirow{2}{*}{ No. } & \multirow[b]{2}{*}{ Kegiatan } & \multicolumn{4}{|c|}{ Rata-rata persentase (\%) } \\
\hline & & $\begin{array}{l}\text { Oleh } \\
\text { Apoteker }\end{array}$ & $\begin{array}{c}\text { Oleh } \\
\text { Asisten } \\
\text { Apoteker }\end{array}$ & $\begin{array}{c}\text { Oleh Apoteker } \\
\text { dan Asisten } \\
\text { Apoteker }\end{array}$ & $\begin{array}{l}\text { Tidak } \\
\text { Dilakukan }\end{array}$ \\
\hline \multirow{7}{*}{1.} & Pelayanan Farmasi Klinik & & & & \\
\hline & a. Pengkajian resep & 61,4 & 7,3 & 17,3 & 14,1 \\
\hline & b. Dispensing & 37,2 & 35,4 & 21,6 & 5,9 \\
\hline & c. Pelayanan Informasi Obat (PIO) & 28,0 & 0,7 & 9,8 & 61,6 \\
\hline & d. Konseling & 53,5 & 0,4 & 9,1 & 37,1 \\
\hline & e. Pemantauan Terapi Obat (PTO) & 20,3 & 0 & 1,8 & 77,9 \\
\hline & f. Monitoring Efek Samping Obat (MESO) & 10,3 & 0 & 0 & 89,7 \\
\hline 2. & $\begin{array}{l}\text { Pengelolaan Sediaan Farmasi, Alat Kesehatan dan } \\
\text { Bahan Medis Habis Pakai }\end{array}$ & 54,0 & 7,4 & 16,9 & 21,7 \\
\hline
\end{tabular}




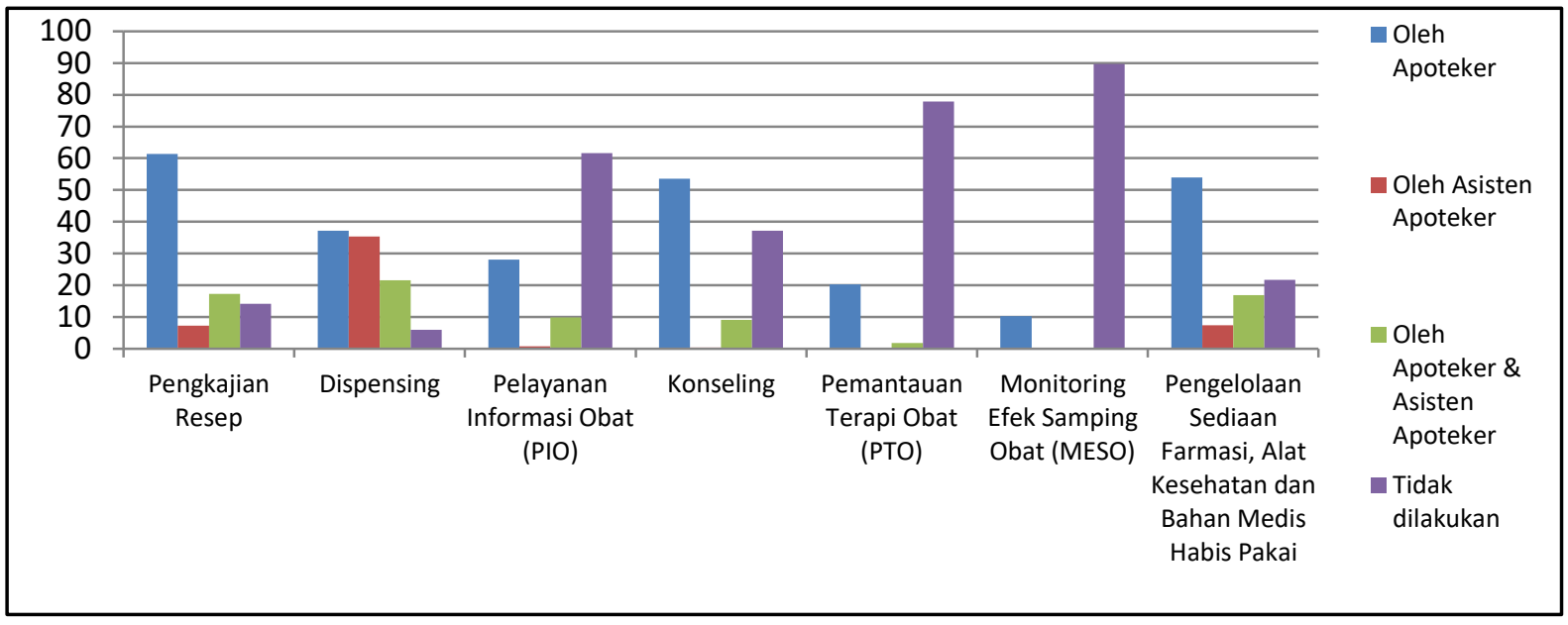

Gambar 1. Pelaksanaan Standar Pelayanan Kefarmasian di Apotek Kota Palu

Hasil penelitian menunjukan apoteker di Kota Palu didominasi oleh jenis kelamin perempuan sebanyak $75 \%$. Hal ini dapat terlihat secara umum pada mahasiswa farmasi dan profesi apoteker lebih didominasi jenis kelamin perempuan. Apoteker yang menjadi responden penelitian sebesar 100\% merupakan Apoteker Pengelola Apotek (APA). Hal ini sesuai dengan data apoteker di apotek yang memiliki apoteker pendamping hanya $8,93 \%$ dari keseluruhan sampel. Sejalan dengan Peraturan Pemerintah RI Nomor 51 tahun $2009{ }^{5}$ tentang pekerjaan kefarmasian pasal 14 ayat 1 disebutkan bahwa setiap fasilitas distribusi atau penyaluran sediaan farmasi berupa obat harus memiliki seorang apoteker. Setiap kegiatan kefarmasian yang dilakukan di apotek harus selalu dalam pengawasan apoteker sehingga dengan adanya apoteker lebih dari satu, akan meningkatkan pelayanan kefarmasian di sarana tersebut.

Responden didominasi oleh apoteker yang memiliki pengalaman sebagai apoteker pengelola apotek selama $>1-5$ tahun yaitu $48,21 \%$. Pengalaman kerja apoteker sebagai apoteker pengelola di apotek, yang dibuktikan dengan lamanya waktu bekerja di apotek tersebut, tentu akan berpengaruh terhadap pengelolaan obat di apotek. Berdasarkan imbalan per bulan, hasil penelitian menunjukkan bahwa sebesar $53,57 \%$ imbalan apoteker dalam interval > Rp. 2.000 .000 - Rp. 3.000.000 per bulan. Hal ini telah sesuai dengan surat edaran Pengurus Daerah Ikatan Apoteker Indonesia Sulawesi Tengah tentang standar gaji apoteker yaitu sebesar Rp. 2.500.000. Walaupun telah ada surat edaran standar gaji yang dikeluarkan PD IAI Sulawesi Tengah tersebut, ternyata $21,43 \%$ apoteker di apotek Kota Palu mandapat imabalan < Rp. 2.000.000. Hal ini tentu dapat berdampak terhadap kinerja apoteker di apotek, tetapi harus dilakukan penelitian lebih lanjut.

Berdasarkan apoteker pendamping (aping) yang dimiliki, didapatkan bahwa 91.07\% apoteker di Apotek Kota Palu tidak memiliki apoteker pendamping. Hal ini bisa dikaitkan dengan data omset apotek yang rendah, seperti terlihat di tabel 2, yang menunjukan bahwa apotek di Kota Palu sebanyak 28,57\% memiliki omset per hari dibawah Rp. 1.000.000. Dari omset tersebut tidak memungkinkan jika dilakukan 
penambahan apoteker yang bekerja di apotek. Keberadaan apoteker di apotek telah sesuai dengan Peraturan Pemerintah RI Nomor 51 Tahun $2009{ }^{5}$, tentang Pekerjaan Kefarmasian pada pasal 20 menyebutkan bahwa dalam menjalankan pekerjaan kefarmasian pada fasilitas pelayanan kefarmasian, apoteker dapat dibantu oleh apoteker pendamping dan/ atau tenaga teknis kefarmasian.

Frekuensi kehadiran apoteker di apotek, didapatkan bahwa sebanyak 51,79\% apoteker di Kota Palu hadir di apotek setiap hari pada jam-jam tertentu. Berdasarkan Dominica ${ }^{6}$, diketahui bahwa terdapat pengaruh kehadiran apoteker terhadap pelayanan kefarmasian di kota Padang. Uji menggunakan uji korelasi dengan SPSS dengan koefisien korelasi positif 0,910 menunjukan hubungan antara variabel tingkat pelayanan kefarmasian dan kehadiran apoteker searah ${ }^{6}$.

Jumlah resep yang dilayani per hari, sebanyak 50,00\% apotek di Kota Palu melayani resep $\leq 5$ lembar per hari. Untuk jumlah resep >30 lembar per hari sebesar $7,14 \%$. Apotek di Kota Palu ada yang bekerjasama dengan dokter praktek dan ada yang tidak. Keberadaan dokter praktek dapat mempengaruhi jumlah lembar resep yang dilayani ataupun omset yang didapatkan apotek per hari nya, tetapi belum diteliti lebih jauh apakah ada pengaruh keberadaan dokter praktek terhadap penerimaan lembar resep dan omset di apotek. Berdasarkan jumlah omset per hari yang didapatkan oleh apotek di Kota Palu, sebesar 28,57\% apotek di Kota Palu memiliki omset $\leq$ Rp. 1.000 .000 dan hanya $6,67 \%$ apotek di Kota Palu memiliki omset $\geq$ Rp. 10.000.000 per hari.

\section{Pelayanan Farmasi Klinik}

Dalam Permenkes No. 73 Tahun 2016 3 , ruang lingkup pelayanan kefarmasian di apotek meliputi 2 (dua) kegiatan, yaitu kegiatan yang bersifat manajerial berupa pengelolaan sediaan farmasi, alat kesehatan, dan bahan medis habis pakai dan pelayanan farmasi klinik. Pelayanan farmasi klinik di apotek Kota Palu dapat terlihat pada tabel 3. Standar pengkajian resep meliputi administrasi, kesesuaian farmasetik dan pertimbangan klinis (Peremenkes No. 73 Tahun 2016). Kegiatan pengkajian resep yang dilakukan di apotek Kota Palu, didominasi oleh apoteker yang melakukan kegiatan tersebut sebesar $61,6 \%$. Hal ini sejalan dengan penelitian Suyono ${ }^{7}$, yang menyimpulkan ratarata apoteker pengelola apotek (APA) di Kota Yogyakarta melakukan skrining persyaratan administratif, kesesuaian farmasetika dan pertimbangan klinis resep selama di apotek sebesar 72,7\%. Pengkajian resep oleh apoteker dapat meminimalisasi terjadinya kesalahan pada pelayanan resep di apotek.

Dari hasil penelitian, dispensing secara keseluruhan di apotek sebesar 36,9\% dilakukan oleh apoteker dan 36,1\% dilakukan oleh asisten apoteker. Kegiatan dispensing merupakan pekerjaan kefarmasian yang dilakukan oleh tenaga kefarmasian yaitu apoteker dan dapat dibantu oleh asisten apoteker. Berdasarkan penelitian ${ }^{8}$ pelayanan resep yang dilakukan asisten apoteker di apotek swasta Jakarta Pusat, berkategori baik sebesar $57 \%$. Walaupun dispensing dilakukan oleh apoteker, tidak luput dapat terjadi kesalahan, seperti telah dilakukan penelitian oleh Ramadha Nita ${ }^{9}$ dalam penelitian yang berjudul studi pendahuluan persepsi apoteker tentang dispensing error di apotek-apotek Kota Banjarmasin. Sebanyak 66,67\% 
responden menyadari telah melakukan kesalahan di dalam proses dispensing dalam 6 bulan terakhir, namun sebagian besar dapat memperkirakan seberapa sering kesalahan tersebut terjadi.

Dispensing seringkali didelegasikan kepada staf/karyawan yang menganggur, yang melakukan kegiatan ini tanpa pengetahuan, pelatihan atau pengawasan. Situasi seperti ini adalah irasional dan berbahaya. Tanggung jawab kebenaran dan mutu obat yang diserahkan kepada pasien terletak seluruhnya pada apoteker pengawas proses dispensing, apoteker dan asisten apoteker yang langsung mengerjakan resep/order obat. ${ }^{10}$

Dari hasil tabel 3, terlihat bahwa standar pelayanan informasi obat di apotek Kota Palu sebesar $62,1 \%$ tidak dilakukan, hanya 27,5\% dilakukan oleh apoteker di apotek Kota Palu. Pelayanan Informasi Obat (PIO) merupakan kegiatan yang dilakukan oleh Apoteker dalam pemberian informasi mengenai obat yang tidak memihak, dievaluasi dengan kritis dan dengan bukti terbaik dalam segala aspek penggunaan obat kepada profesi kesehatan lain, pasien atau masyarakat. Informasi mengenai obat termasuk obat resep, obat bebas dan herbal 11. Pelayanan informasi obat baik infomasi obat resep pasien, maupun informasi obat swamedikasi penting dilakukan di apotek oleh tenaga kefarmasian. Pelayanan informasi obat dilakukan untuk meningkatkan pengetahuan pasien terhadap penyakit dan pengobatanya.

$$
\text { Hasil penelitian menunjukkan, }
$$
apoteker menjawab pertanyaan konsumen/pasien di apotek baik secara lisan maupun tulisan. Kegiatan yang persentase dilakukannya rendah adalah pada kegiatan melakukan penelitian tentang obat dan membuat atau menyampaikan makalah di forum ilmiah. Dalam melakukan informasi obat, terdapat hambatan dalam implementasinya, yaitu hambatan dari sudut pandang apotek sebagai sarana penyedia jasa \& KIE serta hambatan sudut pandang pasien. ${ }^{2}$ Dari hasil kegiatan konseling, sebesar $52,5 \%$ dilakukan oleh apoteker di apotek dan 37,1\% apotek tidak melakukan kegiatan konseling. Konseling merupakan proses interaktif apoteker dengan pasien/keluarga pasien. Konseling dilakukan untuk meningkatkan pengetahuan dan pemahaman serta kesadaran pasien terhadap penggunaan obatnya di samping itu kegiatan tersebut juga dapat dilakukan untuk menyelesaikan masalah yang dihadapi pasien. Berdasarkan Husna ${ }^{12}$, terbukti terdapat pengaruh pemberian konseling farmasis terhadap tingkat kepatuhan penggunaan obat serta hasil terapi pasien DM tipe 2 di Puskesmas.

Pada kegiatan pemantauan obat, sebesar 78,3\% tidak dilakukan di apotek Kota Palu, hanya sebesar 19,9\% apoteker yang melakukan pemantauan terapi obat di apotek. Dari seluruh hasil kuesioner responden, didapat bahwa asisten apoteker sama sekali tidak melakukan kegiatan pemantauan terapi obat. Berdasarkan Permenkes No. 73 Tahun 2016, Pemantauan Terapi Obat (PTO) merupakan proses pemastian terapi obat yang dilakukan secara efektif dan terjangkau oleh apoteker kepada pasien, dengan meminimalkan efek samping dan memaksimalkan efikasi.

Dari hasil penelitian, kegiatankegiatan pada standar monitoring efek samping obat di apotek Kota Palu tidak dilakukan sebesar 89,9\%. Hanya sekitar 
10,1\% MESO dilakukan oleh apoteker. Monitoring efek samping obat merupakan kegiatan pemantauan setiap respon terhadap obat yang merugikan atau tidak diharapkan yang terjadi pada dosis normal yang digunakan pada manusia untuk tujuan profilaksis, diagnosis dan terapi atau memodifikasi fungsi fisiologis ${ }^{11}$. Berdasarkan Standar Kompetensi Apoteker yang dikeluarkan oleh Pengurus Pusat Ikatan Apoteker Indonesia ${ }^{13}$, apoteker memiliki ketrampilan dalam melakukan monitoring efek samping obat yang memuat kegiatan-kegiatan bagian MESO.

\section{Pengelolaan Sediaan Farmasi, Alat} Kesehatan dan Bahan Medis Habis Pakai

Dari hasil di atas pada tabel 4 , standar pengelolaan sediaan farmasi, alat kesehatan dan bahan medis habis pakai pelaksanaannya didominasi dilakukan oleh apoteker sebesar $54,3 \%$. Pengelolaan sediaan farmasi di apotek dilakukan oleh tenaga kefarmasian, baik apoteker maupun asisten apoteker, maupun dilakukan bersama-sama. Tapi dari hasil yang telah dilakukan lebih dari $50 \%$ pengelolaan sediaan farmasi, alat kesehatan dan bahan medis habis pakai dikerjakan langsung oleh apoteker pengelola apotek, tetapi masih ada beberapa apoteker yang tidak melakukan kegiatan tersebut sebesar $21,3 \%$.

Kegiatan pengelolaan sediaan farmasi, didominasi oleh apoteker yang melakukan kegiatan tersebut. Asisten apoteker di apotek Kota Palu rata-rata tidak melakukan kegiatan perencanaan, pengadaan dan pemusnahan sendiri. Pada kegiatan penyimpanan narkotika dan psikotropika sesuai ketentuan, sebesar $34,5 \%$ apotek tidak melakukan kegiatan tersebut, berdasarkan pendekatan dengan apoteker yang menjadi responden, tidak dilakukan kegiatan tersebut dikarenakan apotek tidak memiliki/mengadakan obat-obat golongan narkotik dan psikotropik tersebut. Kegiatan pemusnahan obat kegiatan ini didominasi pengerjaanya oleh apoteker, walaupun sebesar $\pm 40 \%$ kegiatan tersebut tidak dilakukan oleh apotek di Kota Palu. Pada tabel 5, dipaparkan rangkuman pelaksanaan pelayanan kefarmasian di apotek.

Dari hasil diatas kegiatan pelayanan farmasi klinik yang berupa pengkajian resep, dispensing dan konseling didominasi dilakukan oleh apoteker, sedangkan untuk kegiatan pelayanan informasi obat (PIO), pemantauan terapi obat (PTO) dan monitoring efek samping obat (MESO) persentase tidak dilakukan di apotek Kota Palu lebih tinggi. Sedangkan, dalam kegiatan pengelolaan sediaan farmasi, alkes dan BMHP didominasi oleh apoteker yang melakukan kegiatan tersebut.

Kelemahan dari penelitian ini, yaitu tidak dilakukan analisis terhadap sumber daya manusia, sarana dan prasarana yang dimiliki di apotek. Dalam Peremenkes No.73 Tahun 2016 disebutkan bahwa pelayanan kefarmasian di apotek tersebut harus didukung oleh sumber daya manusia, sarana dan prasarana, sehingga kegiatan yang tidak dilakukan tersebut bisa terjadi karena faktor sumber daya manusia yang dimiliki terbatas ataupun sarana prasarana yang dimiliki tidak memadai. $^{3}$

\section{KESIMPULAN}

Pelaksanaan standar kefarmasian yang dilakukan di apotek Kota Palu untuk standar pengkajian resep dilakukan oleh apoteker sebesar $61,6 \%$, dispensing dilakukan oleh apoteker sebesar $36,9 \%$, pelayanan 
informasi obat tidak dilakukan sebesar $62,1 \%$, konseling dilakukan oleh apoteker sebesar $52,5 \%$, pemantauan terapi obat tidak dilakukan sebesar 78,3\%, monitoring efek samping tidak dilakukan sebesar $89,9 \%$ dan pengelolaan obat dilakukan oleh apoteker sebesar $54,3 \%$.

\section{DAFTAR PUSTAKA}

1. Anonim. Undang-Undang RI No. 36 Tahun 2009 Tentang Kesehatan. 2009:77.

2. Satibi, Rokhman MR, Aditama $\mathrm{H}$. Manajemen Apotek. Yogyakarta: Gadjah Mada University Press., 2016.

3. Kemenkes RI. Peraturan Menteri Kesehatan RI No. 73 Tahun 2016 Tentang Standar Pelayanan Kefarmasian di Apotek. 2016.

4. Dinas Kesehatan Provinsi Sulawesi Tengah. Profil Kesehatan Provinsi Sulawesi Tengah Tahun 2016.

5. Anonim. Peraturan Pemerintah Republik Indonesia No. 51 Tahun 2009 Tentang Pekerjaan Kefarmasian. 2009;41.

6. Dominica D, Putra DP, Yulihasri. Pengaruh Kehadiran Apoteker Terhadap Pelayanan Kefarmasian di Apotek di Kota Padang. J Sains Farm Klin 2016; 3: 99107.
7. Suyono. Persepsi Apoteker Pengelola Apotek Di Kota Yogyakarta Terhadap Perannya Dalam Pelayanan Resep Selama Di Apotek. 2006.

8. Herman MJ, Supardi S, Sasanti R, Isnawati A, Muktiningsin S, Apriany $P$. Faktor yang Berhubungan dengan Pelayanan Resep oleh Asisten Apoteker di Apotek. Bul Penelit Kesehat 2004; 32: 119-126.

9. Nita R. Studi Pendahuluan Persepsi Apoteker Tentang Dispensing Error Di Apotek-Apotek Kota Banjarmasin. 2011.

10. Siregar CJ. Farmasi Rumah Sakit, Teori dan Penerapan I. Jakart: EGC, 2003.

11. Kemenkes RI. Peraturan Menteri Kesehatan Republik Indonesia No. 35 Tahun 2014 Tentang Standar Pelayanan Kefarmasian di Apotek. 2014;33.

12. Nadia H, Murti AT, Chairun W. Pengaruh Konseling Farmasis Terhadap Kepatuhan Penggunaan Obat Serta Hasil Terapi Pasien Diabetes Melitus. 5th Urecol Proceding 2017; : 623-630.

13. Ikatan Apoteker Indonesia. Standar Kompetensi Apoteker Indonesia. Standar Kompetensi Apoteker Indonesia, 2016;156. 